dependent Cushing's disease but there was no recurrence after a short course of metyrapone and while totally abstaining from alcohol; although the possibility of cyclical true Cushing's syndrome remained, we think this unlikely. Alcohol abuse should always be considered in the differential diagnosis of Cushing's syndrome. Abstinence does not necessarily lead to rapid clinical improvement; in this case the signs and biochemical abnormalities persisted for over two months and closely mimicked pituitary-dependent Cushing's disease.

${ }^{1}$ Rees LH, Besser GM, Jeffcoate WJ, et al. Alcohol-induced pseudoCushing's syndrome. Lancet $1977 ; \mathrm{i}: 726-8$.

${ }^{2}$ Smals AGH, Nio KT, Knober JM, Ruland CM, Kloffenburg PWE. Alcohol-induced Cushingoid syndrome. $\mathcal{F}$ R Coll Physicians Lond 1977; 12:36-41.

3 Paton A. Alcohol-induced Cushingoid syndrome. Br Med $\mathcal{F}$ 1976; ;iv: 1504.

4 Lamberts SWJ, Klijn GM, De Jong FH, Birkenhager JC. Hormone secretion in alcohol-induced pseudo-Cushing's syndrome. $\mathcal{F} A M A$ $1979 ; 242: 1640-8$

${ }^{5}$ Frijria R, Angelli A. Alcohol-induced pseudo-Cushing's syndrome. Lancet $1977 ; \mathrm{i}: 1050-1$.

(Accepted 6 fanuary 1981)

Selly Oak Hospital, Birmingham B29 6JD

$R M$ JENKINS, MRCP, registrar in medicine

$M$ MCB PAGE, MD, MRCP, consultant physician

\section{Remission of primary pulmonary hypertension during treatment with diazoxide}

Until recently primary pulmonary hypertension was an untreatable illness characterised by steady deterioration and death about three years after diagnosis. Short-lived reductions in pulmonary vascular months after starting diazoxide there were no clinical signs of pulmonary hypertension and the chest radiograph and electrocardiogram were normal. Pulmonary artery pressure after 15 months' treatment was $25 / 12 \mathrm{~mm} \mathrm{Hg}$ and the patient was asymptomatic. Diazoxide was then stopped. The patient remained well for six months, when she noticed a return of the dyspnoea. Physical signs of pulmonary hypertension were again evident and the electrocardiogram showed right-sided changes. Cardiac catheterisation confirmed the relapse, the pulmonary artery pressure being $100 / 40 \mathrm{~mm} \mathrm{Hg}$. Since then she has been taking increasing doses of hydrallazine and is once more improving symptomatically. Haemodynamic data are summarised in the table.

\section{Comment}

In one patient with primary pulmonary hypertension we have shown how the effects of the disease may be completely ameliorated by treatment with the vasodilator drug diazoxide. We believe that all patients with this condition should be given a trial of treatment with drugs of this type. Our experience suggests that a successful response is more likely if the illness is treated at an early stage, when the pulmonary hypertension is still labile and before irreversible changes have occurred in the pulmonary arteries.

It is interesting that the pulmonary hypertension in our patient returned when diazoxide was stopped; this suggests that the underlying disease process responsible for the development of pulmonary hypertension is still active.

${ }^{1}$ Shettigar UR, Hultgren HN, Specter M, Martin R, Davies DH. Primary pulmonary hypertension: favourable effect of isoproterenol. $N$ Engl $\mathcal{f}$ Med 1976;295:1414-5.

2 Dresdale DT, Michtom RJ, Schultz M. Recent studies in primary pulmonary hypertension including pharmacodynamic observations on pulmonary vascular resistance. Bull NY Acad Med 1954 ;30:195-207.

${ }^{3}$ Wang SWS, Pohl JEF, Rowlands DJ, Wade EG. Diazoxide in treatment of primary pulmonary hypertension. Br Heart $f$ 1978;40:572-4.

4 Rubin LJ, Peter RH. Oral hydralazine therapy for primary pulmonary hypertension. N Englf Med $1980 ; 302: 69-73$.

${ }^{5}$ Honey M, Cotter L, Davies N, Denison D. Clinical and haemodynamic effects of diazoxide in primary pulmonary hypertension. Thorax 1980; $35: 269-76$.

Haemodynamic data of patient with primary pulmonary hypertension

\begin{tabular}{|c|c|c|c|c|c|c|}
\hline & \multicolumn{3}{|c|}{$\begin{array}{l}\text { Pulmonary artery pressure } \\
(\mathbf{m m ~} \mathbf{~ H g})\end{array}$} & \multirow{2}{*}{$\begin{array}{c}\begin{array}{c}\text { Pulmonary artery } \\
\text { wedge pressure } \\
\text { (mm Hg) }\end{array} \\
\text { Mean } \\
\end{array}$} & \multirow[t]{2}{*}{$\begin{array}{l}\text { Cardiac output } \\
(1 / \mathrm{min})\end{array}$} & \multirow[t]{2}{*}{$\begin{array}{l}\text { Pulmonary vascular } \\
\text { resistance } \\
\text { (units) }\end{array}$} \\
\hline & Systolic & Diastolic & Mean & & & \\
\hline \multirow{4}{*}{$\begin{array}{l}\text { Before treatment } \\
\text { After five months' } \\
\text { treatment } \\
\text { After } 15 \text { months' } \\
\text { treatment } \\
\text { Seven months after } \\
\text { stopping diazoxide }\end{array}$} & 65 & 35 & 42 & 4 & $5 \cdot 4$ & $7 \cdot 0$ \\
\hline & 37 & 20 & 25 & 9 & $6 \cdot 8$ & $2 \cdot 4$ \\
\hline & 25 & 12 & 17 & 3 & $6 \cdot 0$ & $2 \cdot 3$ \\
\hline & 100 & 40 & 60 & 8 & 3.8 & $13 \cdot 7$ \\
\hline
\end{tabular}

resistance have been obtained by intravenous injections of isoprenaline and tolazoline, ${ }^{12}$ but not until 1978 was sustained improvement in the pulmonary hypertension described after treatment with oral diazoxide. $^{3}$ Of three patients treated two improved, one symptomatically and the other both symptomatically and haemodynamically for more than two years. Further studies have confirmed that pulmonary artery pressures may be reduced by diazoxide and hydrallazine ${ }^{4}{ }^{5}$ but in no patient has a complete remission of the pulmonary hypertension been achieved. We describe a patient with primary pulmonary hypertension in whom pulmonary artery pressures returned to normal during treatment with diazoxide.

\section{Case report}

A 31-year-old housewife complained of fainting attacks since her last pregnancy 21 months earlier and exertional breathlessness for 12 months. Physical examination showed signs of severe pulmonary arterial hypertension for which investigation revealed no cause. Pulmonary artery pressure was $65 / 35 \mathrm{~mm} \mathrm{Hg}$ and pulmonary wedge pressure was normal. The patient was treated with warfarin for anticoagulation and started on oral diazoxide, the dose being slowly increased to $600 \mathrm{mg}$ a day. Side effects included fluid retention, hyperglycaemia, and hypertrichosis. After three months' treatment the patient's symptoms had improved, radiographs showed a reduction in heart size, and the electrocardiographic changes of right heart strain were less evident. Repeat cardiac catheterisation showed a pulmonary artery pressure of $37 / 20 \mathrm{~mm} \mathrm{Hg}$ and normal pulmonary vascular resistance. Nine
(Accepted 9 fanuary 1981)

The Ipswich Hospital, Heath Road Wing, Ipswich, Suffolk IP4 5PD D RUSSELL HALL, MD, MRCP, consultant physician

Papworth Hospital, Papworth Everard, Cambridge CB3 8RE MICHAEL C PETCH, MD, MRCP, consultant cardiologist

\section{Transposons and trimethoprim resistance}

The release of trimethoprim for use alone has led to speculation on possible effects on the incidence of trimethoprim-resistant bacteria. ${ }^{1}$ The incidence of trimethoprim resistance has been increasing among hospital bacteria but is still low in strains causing urinary infections in the community outside hospital. ${ }^{1}$ Nearly all trimethoprim-resistant bacteria isolated from clinical material are also sulphonamide-resistant.

Plasmids are DNA molecules that replicate autonomously in bacteria and may be transferred from one bacterium to another, a replica remaining in the original cell. $\mathrm{R}$ plasmids encode antibiotic resistance genes and disseminate resistance among bacteria. Transpo- 